\title{
Phylogeographic differentiation in Sorex araneus: morphology in relation to geography and karyotype
}

\section{P. David Polly}

\begin{abstract}
Findings of gene flow across hybrid zones between karyotypic races of the common shrew, Sorex araneus Linnaeus, 1758, have contributed to the debate over the role of chromosomal changes in speciation. The correlation between chromosomal and morphological evolution was examined here across the full geographic range of the species. Previous studies on selected karyotypic races yielded ambiguous results: some found significant differences between races, but others concluded that local variation was more important than karyotype for morphological structuring. Forty three samples, representing 24 karyotypic races and three species were studied here. Geometric morphometrics were used to determine whether karyotypic, geographic or population-level structuring was present in the size and shape of molars, skulls and mandibles. Significant structuring was found in all traits among populations, among karyotypic races, among phylogenetic groups of karyotypic races and among species, greatest among populations $\left(F_{S T}\right.$ ranged from 0.08 to 0.11$)$ and groups $\left(F_{S T} 0.04\right.$ to 0.15$)$. Within $S$. araneus structuring was greater in skull centroid size and molar shape than in skull or mandible shape. Large-scale east-to-west clines were found in molar and skull shape. The skull cline is probably associated with changes in the frequency of the upper fifth antemolar. Mandible shape was not highly differentiated between karyotypic races compared to molar shape, but it was better at discriminating among karyotypic groups and species. It is likely that fossil specimens can be determined to the level of karyotypic group, but not to a specific karyotypic race.
\end{abstract}

KEY WORDS: $F_{S T}$, geometric morphometrics, karyotypic race, phenotypic evolution, Sorex araneus.

P. David Polly [pdpolly@indiana.edu], Department of Geological Sciences, Indiana University, Bloomington, Indiana 47405, USA.

\section{Филогеографическая дифференциация у Sorex araneus: морфология в связи с географией и кариотипом}

\section{П.Д. Полли}

РЕЗЮМЕ. Недавнее открытие значительного потока генов через гибридные зоны между хромосомными расами обыкновенной бурозубки Sorex araneus послужило новым импульсом для дискуссии о роли хромосомных перестроек в видообразовании. В настоящей работе оценивается корреляция между эволюцией хромосом и морфологических признаков на всем ареале этого вида. Результаты предшествующих исследований отдельных хромосомных рас оказались неоднозначными: в то время как в одних случаях была обнаружена достоверная разница между расами, в других морфологическая подразделенность популяций определялась в большей степени локальными различиями, нежели кариотипом. В настоящей работе методом геометрической морфометрии размеров тела, формы моляра, черепа и нижней челюсти была произведена оценка морфологической структурированности в 43 выборках, представляющих 25 хромосомных рас и три вида землероек. Структурированность между популяциями, расами, кариотипическими группами и видами была достоверно подтверждена для всех исследованных признаков. Наиболее отчетливая подразделенность наблюдалась между популяциями $\left(F_{S T}\right.$ от 0.08 до 0.11$)$ и кариотипическими группами $\left(F_{S T}\right.$ от 0.04 до 0.15$)$. Внутри вида $S$. araneus подразделенность по центроиду черепа и по форме моляра была выражена существеннее, чем по форме черепа и нижней челюсти. В результате работы была выявлена клинальная изменчивость (с востока на запад) формы черепа и моляра. Изменение формы черепа связано, по-видимому, с изменением частоты верхнего пятого антемоляра. Форма нижней челюсти, которая прежде служила стандартным объектом морфометрических исследований у S. araneus, оказалась более слабым дискриминатором между хромосомными расами по сравнению с формой моляра, однако лучше остальных признаков дискриминировала виды. По-видимому, палеонтологические материалы вида Sorex araneus могут быть идентифицированы до уровня кариотипических групп, но не хромосомных рас.

КЛЮЧЕВЫЕ СЛОВА: $F_{S T}$, геометрическая морфометрия, хромосомные расы, эволюция фенотипа, Sorex araneus. 


\section{Introduction}

Do chromosomal mutations lead to speciation? Rearrangements of chromosome arms can cause incompatibilities that inhibit gene flow and allow genetic differences to accumulate. With the observation that more than 90 percent of speciation events have associated chromosomal rearrangements, karyotypic change is arguably a major factor in speciation (White, 1978). But the discovery that gene flow can cross karyotype boundaries has led some to conclude that chromosomal variation is unconnected to speciation and long-term genetic differentiation. Bengtsson \& Frykman (1990) went so far as to argue that karyotypically fragmented species like Sorex araneus are in the process of "despeciation", bleeding through secondary hybrid zones the genetic structure that built up during past periods of glacial isolation. Several examples of gene flow across $S$. araneus racial hybrid zones now support this hypothesis (Frykman et al., 1983; Frykman \& Bengtsson, 1984; Searle, 1985; Wójcik \& Wójcik, 1994; Ratkiewicz et al., 2002; Balloux et al., 2003; Fivaz et al., 2003; Andersson, 2004), as do examples of morphometric differentiation that are unassociated with racial boundaries (Searle \& Thorpe, 1987; Wójcik et al., 2000; Banaszek et al., 2003). Nevertheless, Hausser (1994) considered that chromosomal rearrangements do lead to genetic differentiation. He pointed out that gene flow between parapatric races depends on the size of their metacentrics and on the way in which they partition local habitats. Further he argued that even though gene flow may occur in some situations, these are the exception rather than the rule: normally gene flow does not occur between karyotypically distinct groups; chromosome rearrangements should on the whole lead to genetic differentiation and speciation. Thus, the issue of how karyotypic variation relates to other types of differentiation remains of interest. As emphasized by Wójcik et al. (2000), genetic differentiation at broad spatial scales needs more study.

In this paper, variation among karyotypic groups of $S$. araneus was studied across its entire geographic range. The effect of karyotype on morphology was tested at four hierarchical levels: within races, between races, between phylogenetic groups of karyotypic races and between sibling species. Robertsonian variation divides the species into nearly 70 races (Wójcik et al., 2003) that are grouped into four putative phylogenetic groups: the western European karyotypic group with races from Britain to the Ukraine that share the $h i$ and, usually, gm metacentrics; the eastern European karyotypic group with five races in Poland and adjacent areas sharing the metacentric $g r$; the northern European group with races from northern Scandinavia through the Urals to western Siberia that share the metacentric ip; and the Siberian group with races in south-central Siberia that share metacentrics $g k$ and $h i$ (Searle, 1984; Wójcik, 1993; Ivanitskaya, 1994; Polyakov et al., 2001). The Valais race, now elevated to species rank as $S$. antinorii Bonaparte, 1840, is the sister-group to the rest, and the
Cordon race of eastern France and Switzerland and Pelister race of the Balkans have predominantly acrocentric karyotypes that are thought to represent the ancestral chromosome condition before the origin of the metacentric groups. The races are characterized by different combinations of metacentric chromosomes which arose through Robertsonian fusions and wholearm reciprocal translocations (WARTs; Halkka et al., 1987; Searle et al., 1990; Hausser, 1994; Fredga, 1996; Searle \& Wójcik, 1998). In this study, the karyotypic diversity of Sorex araneus was represented by 24 races (Fig. 1). Two of its morphologically similar sibling species were also represented, S. antinorii and S. coronatus Millet, 1828. The inclusion of samples from different races, karyotypic groups and species allows the effect of chromosomal differences to be assessed globally rather than relying on individual case studies.

\section{Material and methods}

Forty three samples belonging to Sorex araneus (24 karyotypic races), $S$. antinorii (formerly the Valais race) and $S$. coronatus were studied, totalling 495 individuals (Fig. 1, Tab. 1). The karyotype of most of the samples was known directly from previous research by other authors (see Acknowledgements); the karyotypes of the remaining samples were inferred from their geographic position. The karyotype of one of the latter (Neusiedler See, Austria) was ambiguous, belonging either to the Drnholec race or to an Ulm $\times$ Drnholec hybrid population (Zima et al., 2003; J. Zima, pers. comm.). Only immature animals were included in the analysis to minimize the effect of age differences on our results. In shrews, an immature individual is one that has reached its adult size, but which has not overwintered and reproduced (Churchfield, 1990). In other words, juvenile and aged individuals were excluded. Age determination was based on tooth wear, thus excluding also individuals with excessively worn teeth. Sexual dimorphism is negligible in shrews so the sexes were pooled.

The skull, mandible and first lower molar of each specimen were photographed in ventral, lateral and functional occlusal views, respectively. The shape of each specimen was represented with two-dimensional Cartesian landmarks (Fig. 2). Lower molars were photographed and landmarked five times each then averaged to minimize orientation error (Polly, 2003).

Centroid size was calculated for each specimen as the square root of the sum of the squared distances between the landmarks and the centroid (Bookstein, 1991). Centroid size was used because it is mathematically independent of shape; linear measurements such as skull length may be biased if they lie along major axes of shape variation. Centroid size was calculated for skulls and mandibles, but not molars because of the difficulty of accurately fitting a scale bar into those photographs.

Each sample was Procrustes superimposed and projected orthogonally into shape tangent space (Rohlf, 


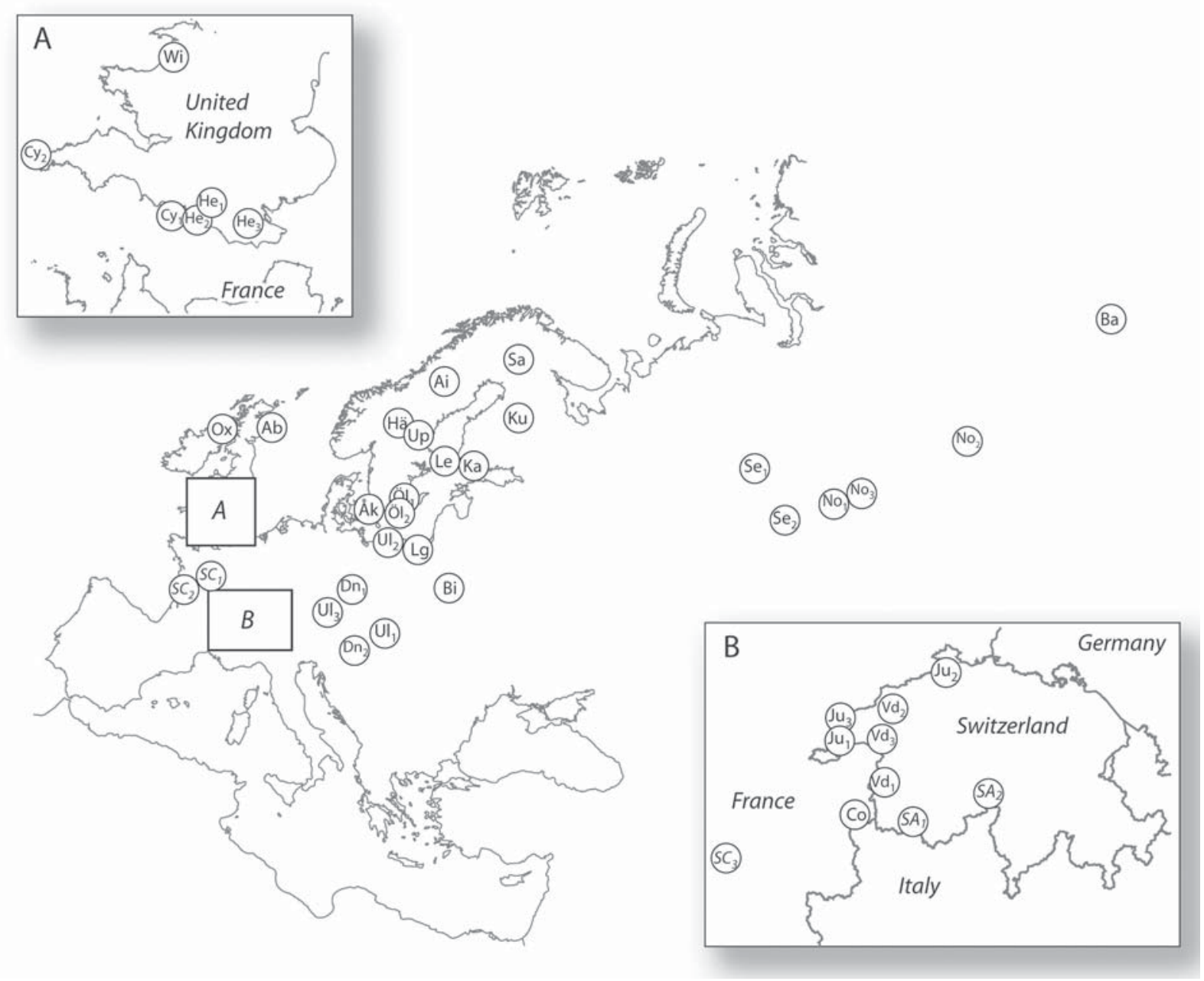

Figure 1. Map showing the location of samples used in this study. The karyotypic race of each sample is indicated by abbreviation (see Tab. 1).

Table 1. Samples used in this study. Latitude and longitude are in decimal degrees.

\begin{tabular}{|c|c|c|c|c|c|c|}
\hline Abbr & Taxon & Location & Lat & Long & $\mathrm{n}$ & Group \\
\hline $\mathrm{SC}_{1}$ & S. coronatus & La Boue, Loir-et-Cher, France ${ }^{3}$ & 47.55 & 1.62 & $7 / 7 / 6$ & CORO \\
\hline $\mathrm{SC}_{2}$ & S. coronatus & Guè de Velluire, Vendée, France ${ }^{3}$ & 46.37 & -0.92 & $8 / 7 / 8$ & CORO \\
\hline $\mathrm{SC}_{3}$ & S. coronatus & Col de la Croix Perrin, Vercors, France ${ }^{2}$ & 44.97 & 5.42 & $9 / 9 / 10$ & CORO \\
\hline $\mathrm{SA}_{1}$ & S. antinorii & La Monta Arolla, Valais, Switzerland ${ }^{2}$ & 46.03 & 7.49 & $10 / 9 / 10$ & ANTI \\
\hline $\mathrm{SA}_{2}$ & S. antinorii & ${\text { Haslital, Switzerland }{ }^{2}}^{2}$ & 46.58 & 8.33 & $21 / 18 / 21$ & ANTI \\
\hline $\mathrm{Ab}$ & Aberdeen race & Dumbreck, Scotland, UK ${ }^{7}$ & 57.35 & -2.18 & $17 / 15 / 18$ & WEKG \\
\hline $\mathrm{Ai}$ & Abisko race & Vilhelmina, Lappmark, Sweden ${ }^{5}$ & 64.62 & 16.66 & 7/7/7 & NEKG \\
\hline Åk & Åkarp race & Everlöv, Skảne, Sweden 5 & 55.66 & 13.48 & $15 / 11 / 15$ & WEKG \\
\hline $\mathrm{Ba}$ & Baikal race & Baikal, Siberia, Russia $^{1}$ & 53.30 & 109.20 & $5 / 5 / 4$ & SKG \\
\hline $\mathrm{Bi}$ & Białowieża race & Białowieża Forest, Poland ${ }^{4}$ & 52.70 & 23.92 & $43 / 31 / 34$ & EEKG \\
\hline $\mathrm{Cy}_{1}$ & Chys auster race & Arreton, Isle of Wight, $\mathrm{UK}^{7}$ & 50.67 & -1.25 & $9 / 9 / 9$ & WEKG \\
\hline $\mathrm{Cy}_{2}$ & Chysauster race & Chysauster, Cornwall, $\mathrm{UK}^{7}$ & 50.17 & -5.52 & $9 / 7 / 10$ & WEKG \\
\hline Co & Cordon race & Les Houches, Haute-Savoie, France ${ }^{2}$ & 45.89 & 6.80 & $10 / 9 / 10$ & ACRO \\
\hline
\end{tabular}


Table 1 (continued).

\begin{tabular}{|c|c|c|c|c|c|c|}
\hline Abbr & Taxon & Location & Lat & Long & $\mathrm{n}$ & Group \\
\hline $\mathrm{Dn}_{1}$ & Drnholec race & Filipov, Bohemia, Czech Republic ${ }^{1}$ & 50.83 & 14.37 & $14 / 13 / 16$ & WEKG \\
\hline $\mathrm{Dn}_{2}$ & Drnholec race & Neusidler See, Aus tria $^{2}$ & 47.89 & 16.65 & $8 / 9 / 9$ & WEKG \\
\hline $\mathrm{Ha}$ & Hällefors race & Bergobacken, Transtrand, Sweden ${ }^{5}$ & 61.06 & 13.19 & $16 / 9 / 16$ & WEKG \\
\hline $\mathrm{He}_{1}$ & Hermitage race & Alice Holt Forest, Surrey, UK ${ }^{6}$ & 51.21 & -0.79 & 9/9/9 & WEKG \\
\hline $\mathrm{He}_{2}$ & Hermitage race & Hunston, Surrey, UK ${ }^{7}$ & 50.80 & -0.82 & $16 / 9 / 16$ & WEKG \\
\hline $\mathrm{He}_{3}$ & Hermitage race & Twys senden, Kent, UK ${ }^{7}$ & 51.10 & 0.46 & $12 / 9 / 12$ & WEKG \\
\hline $\mathrm{Ju}_{1}$ & Jura race & Bassins les Pralets, Vaud, Switzerland ${ }^{2}$ & 46.47 & 6.25 & $7 / 8 / 8$ & WEKG \\
\hline $\mathrm{Ju}_{2}$ & Jura race & Bellelay, Bern, Switzerland ${ }^{2}$ & 47.27 & 7.17 & $4 / 4 / 4$ & WEKG \\
\hline $\mathrm{Ju}_{3}$ & Jura race & Chalet à Roch, Vaud, Switzerland ${ }^{2}$ & 46.56 & 6.23 & $4 / 4 / 4$ & WEKG \\
\hline $\mathrm{Ka}$ & Kalvitsa race & Tvärminne Station, Finland ${ }^{2}$ & 59.87 & 23.22 & $14 / 14 / 14$ & NEKG \\
\hline $\mathrm{Ku}$ & Kuhmo Race & Sonkajärvi, Finland ${ }^{2}$ & 63.79 & 27.45 & $3 / 3 / 3$ & NEKG \\
\hline Lg & Łęgucki Młyn race & Górowo Iłowieckie, Poland ${ }^{4}$ & 54.30 & 20.52 & $15 / 14 / 12$ & EEKG \\
\hline Le & Lemland race & Åland, Eckero, Finland ${ }^{2}$ & 60.21 & 19.62 & $19 / 19 / 19$ & NEKG \\
\hline $\mathrm{No}_{1}$ & $\begin{array}{l}\text { Novosibirsk } \times \text { Serov } \\
\text { interracial hybrids }\end{array}$ & Kurgan, West Siberia, Russia ${ }^{1}$ & 55.95 & 65.95 & $3 / 3 / 3$ & NEKG \\
\hline $\mathrm{No}_{2}$ & Novosibirsk race & Yurga, West Siberia, Russia ${ }^{1}$ & 55.60 & 84.95 & $3 / 4 / 4$ & NEKG \\
\hline $\mathrm{No}_{3}$ & Novosibirsk race & Abatskii, West Siberia, Russia ${ }^{1}$ & 56.25 & 70.67 & $4 / 5 / 5$ & NEKG \\
\hline $\mathrm{O}_{1}$ & Öland race & Karum, Öland, Sweden ${ }^{5}$ & 56.88 & 16.80 & $8 / 8 / 6$ & WEKG \\
\hline $\mathrm{O}_{2}$ & Öland race & Southern tip, Öland, Sweden ${ }^{5}$ & 56.21 & 16.40 & $7 / 5 / 6$ & WEKG \\
\hline Ox & Oxford race & Islay, Scotland, UK ${ }^{7}$ & 55.63 & -6.15 & $8 / 4 / 8$ & WEKG \\
\hline $\mathrm{Sa}$ & Savukoski race & Luosto, Lappmark, Sweden ${ }^{5}$ & 67.21 & 26.74 & $3 / 3 / 3$ & NEKG \\
\hline $\mathrm{Se}_{1}$ & Serov race & Serov, Urals, Russia ${ }^{1}$ & 59.90 & 60.22 & $3 / 4 / 5$ & NEKG \\
\hline $\mathrm{Se}_{2}$ & Serov race & Chelyabinsk, Siberia, Russia ${ }^{1}$ & 55.95 & 61.25 & $8 / 7 / 4$ & NEKG \\
\hline $\mathrm{Ul}_{1}$ & Ulm race & Belanské Tatry, Slovakia $^{1}$ & 49.14 & 19.01 & $20 / 17 / 20$ & WEKG \\
\hline $\mathrm{Ul}_{2}$ & Ulm race & Stary Kraków, Poland ${ }^{4}$ & 54.45 & 16.58 & $15 / 14 / 12$ & WEKG \\
\hline $\mathrm{Ul}_{3}$ & Ulm race & Ruda, Bohemia, Czech Republic ${ }^{1}$ & 49.68 & 14.17 & $6 / 6 / 4$ & WEKG \\
\hline Up & Uppsala race & Boda, Hälsingland, Sweden ${ }^{5}$ & 60.99 & 15.23 & $13 / 13 / 12$ & WEKG \\
\hline $\mathrm{Vd}_{1}$ & Vaud race & Bex, Vaud, Switzerland ${ }^{2}$ & 46.25 & 7.00 & $6 / 6 / 6$ & WEKG \\
\hline $\mathrm{Vd}_{2}$ & Vaud race & Champ-Pittet, Vaud, Switerland ${ }^{2}$ & 46.78 & 6.67 & $14 / 14 / 14$ & WEKG \\
\hline $\mathrm{Vd}_{3}$ & Vaud race & Le Jourat, Vaud, Switzerland ${ }^{2}$ & 46.58 & 6.68 & $12 / 11 / 12$ & WEKG \\
\hline Wi & Wirral race & Dolgellau, Wales, $\mathrm{UK}^{7}$ & 52.75 & -3.88 & $13 / 12 / 12$ & WEKG \\
\hline
\end{tabular}

Sample sizes (n) are for lower molars / skulls / mandibles. Group abbreviations: CORO — S. coronatus; ANTI — S. antinorii; WEKG western European karyotypic group; EEKG - eastern European karyotypic group; NEKG — northern European karyotypic group; SKG Siberian karyotypic group; ACRO - acrocentric race. Samples are from: 'Institute of Vertebrae Biology, Czech Academy of Sciences, Brno, Czech Republic; ${ }^{2}$ Institute of Zoology and Animal Ecology, University of Lausanne, Switzerland; ${ }^{3}$ Muséum d'histoire naturelle, Genève, Switzerland, ${ }^{4}$ Mammal Research Institute, Polish Academy of Sciences, Białowieża, Poland; ${ }^{5}$ Naturhistoriska riksmuseet, Stockholm, Sweden; ${ }^{6}$ Department of Biological Sciences, Queen Mary, University of London, UK; ${ }^{7}$ Department of Biology, University of York, York, UK.

1990; Rohlf \& Slice, 1990). Sample means were then calculated and jointly superimposed. Principal components scores were used as shape variables for statistical analysis. Scores were calculated by subtracting the mean from each sample (or group of sample means), calculating the covariance matrix of the residuals, and projecting the residuals onto their principal component axes (Dryden \& Mardia, 1998). Shape variables were used for the discriminant function analysis described below. Principal components plots were used to explore shape variation for geographic and taxonomic associations.

Isolation by distance was measured by plotting pairwise morphometric distance (Euclidean distance between centroid sizes or Procrustes distance between sample means) against geographic distance. A linear regression line was used to illustrate the relationship, 


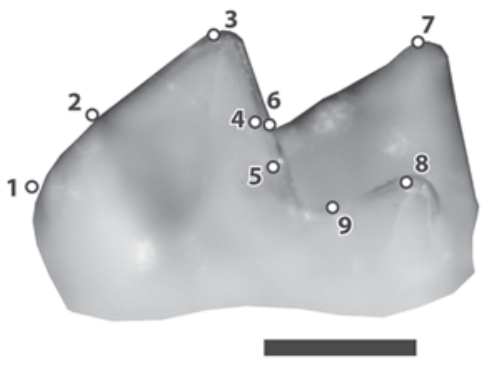

A

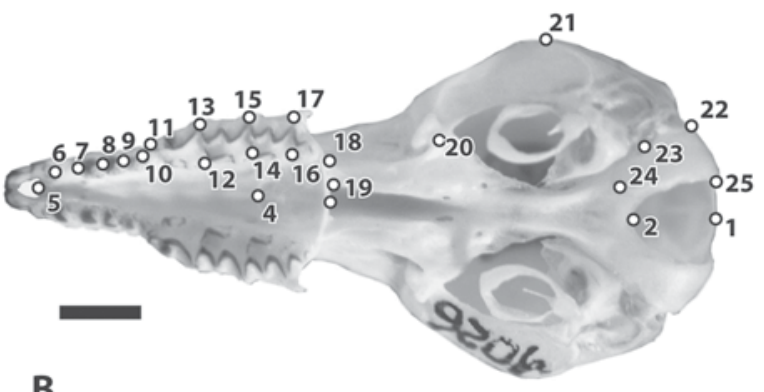

B

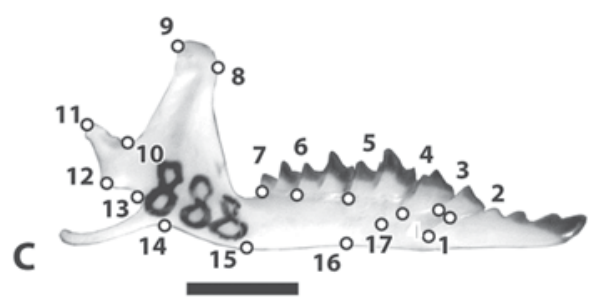

Figure 2. Geometric landmarks used in this study: landmarks of the lower first right molar in occlusal functional view (mesial to the right and buccal to the top) (A); landmarks of the skull in ventral view (B); landmarks of the mandible in lateral view (C). Scale bar in A is $0.5 \mathrm{~mm}$, scale bars in B and $\mathrm{D}$ are $2.0 \mathrm{~mm}$.

but significance was assessed using a Mantel test using 100,000 random permutations (Manly, 1991). The correlation $(R)$ between morphological and geographic distance was estimated using the normalized Mantel- $Z$ statistic. Sorex coronatus samples were not included in the isolation by distance study, but $S$. antinorii was because it was long considered to be a karyotypic race of $S$. araneus (Brünner et al., 2002).

Structuring at the levels of population, race, group and species was assessed using $F$-statistics. $F_{S T}$, the proportion of between-group to within-group variance (Wright, 1951; Lande, 1992; Spitze, 1993), was estimated for skull centroid size, skull shape, mandibular shape and molar shape. To remove sample size bias, a jackknife procedure was used (Weir and Cockerham, 1984). One thousand jackknife iterations were performed in which a random member of each group was dropped and the $F_{S T}$ statistic recalculated (Manly, 1991). By iteratively dropping all samples, the jackknife procedure minimizes the effects of small sample sizes and helps incorporate their effects into the standard error. The jackknife statistic $\left(F_{S T} *\right)$ was calculated as

$$
F_{S T}^{*}=\frac{(n-1-k) S S B^{*}}{(k-1)\left(S S W^{*}+S S B^{*}\right)},
$$

where $S S B^{*}$ was the sum of squared distances between group means and the grand mean, $S S W^{*}$ was the sum of squared distances between individuals and their group mean, $n$ was the sample size, and $k$ was the number of groups. The asterisk $(*)$ indicates that the statistic was calculated from the jackknifed sample. $F_{S T}$ was calculated as the mean of the $1,000 F_{S T}{ }^{*}$ estimates, and the standard error of $F_{S T}$ was estimated as their standard deviation. Spitze (1993) proposed the notation $Q_{S T}$ for $F_{S T}$ calculated from quantitative data such as the ones in this study to distinguish it from $F_{S T}$ calculated from molecular data, for which he proposed the notation $G_{S T}$; some authors have adopted Spitze's notation for $Q_{S T}$, but not $G_{S T}$. To avoid misunderstanding and the proliferation of data-specific notations, $F_{S T}$ was used here for quantitative data. Note that the data in this study are phenotypic, not genotypic.

A randomization test was also used to assess whether karyotypic races are morphologically differentiated from one another. If races are differentiated, then morphometric distances within a race should be smaller than those between random populations when geographic distance is held constant. To test this, geographic effects were first removed by regressing pairwise Procrustes distances between sample means onto geographic distance. Then the residual Procrustes distances of pairs belonging to the same race $(n=18)$ were compared to a distribution of 100,000 distances among 18 random pairs. Random pairs in any one sampling could be from different races or the same race depending on chance. Races were considered to be differentiated if the real distances between pairs of the same race were smaller than $95 \%$ of the random distribution $(\alpha=0.05)$. Sorex coronatus and $S$. antinorii were excluded from this test.

Discriminant function analysis (DFA) was used to determine the accuracy with which specimens can be assigned to karyotypic group based on morphology. DFA finds canonical axes that best separate pre-defined groups, unlike PCA which finds an axis system whose first axis is aligned along the greatest variance in the data. Cross-validation determines the accuracy with which each specimen is classified by the discriminant functions. The Sorex araneus samples were classified into the western European karyotypic group (WEKG), the eastern European karyotypic group (EEKG) and the northern European karyotypic group (NEKG) (Searle \& Wójcik, 1998; Polyakov et al., 2001). S. coronatus (CORO) and $S$. antinorii (ANTI) samples were grouped by species. Note that the groupings of the Siberian races are still problematic (Polyakov et al., 2001). The acrocentric Cordon race and the Baikal race (Siberian karotypic group) were excluded from this part of the analysis because only one sample was available for each. Only those shape variables that collectively accounted for $90 \%$ of the variation in each data set were 


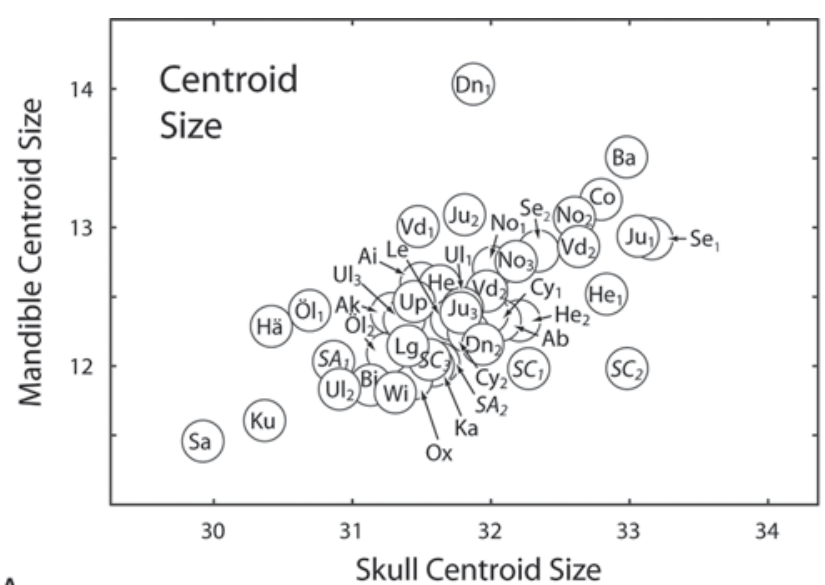

A

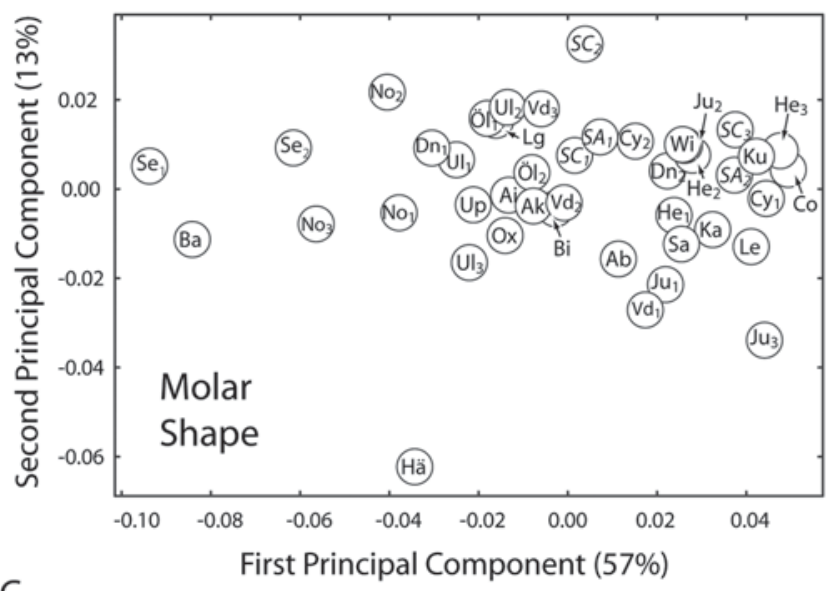

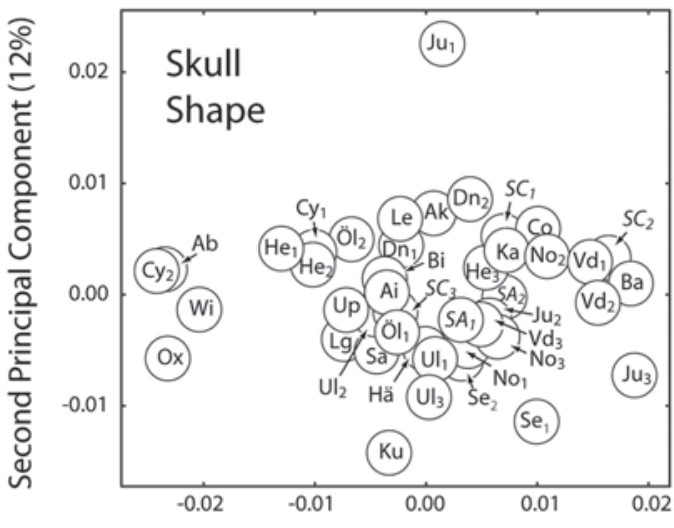

B

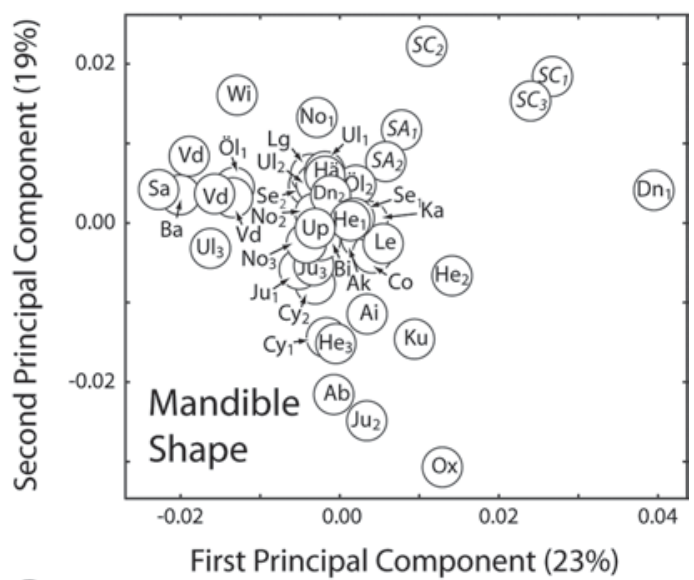

D

Figure 3. Morphological variation in four traits: variation in mandible and skull centroid size (A); variation on the first two principal components of skull shape (B); variation on the first two principal components of molar shape (C); variation on the first two principal components of mandible shape (D). Abbreviations as in Fig. 1 and Tab. 1.

used for DFA classification: for molars it was the first six PCs, for skulls it was the first 11, and for mandibles it was the first 10. Skull and mandible centroid sizes were combined for analysis of size data. This analysis was performed using sample means, not individual shrews.

All analyses except DFA were performed in Mathematica $($ 5.2. The DFA was performed in Statistica ( 6.0. Landmark coordinates were collected with tpsDig 1.40 by F. James Rohlf.

\section{Results}

\section{Geographic patterns of variation}

Size. Skull and mandible size varied considerably among species, karyotypic groups and races, with no clear structure at any level (Fig. 3A). The species were not separated by size, with both Sorex antinorii and $S$. coronatus falling within the range of $S$. araneus. $S$. coronatus was a marginal outlier in Fig. $3 \mathrm{~A}$ because it has a proportionally larger skull than mandible. Samples from the same karyotypic race were usually similar in size, but not exclusively so (e.g., Novosibirsk), but others showed considerable variation within the race (e.g., Jura). The Filipov Drnholec sample $\left(\mathrm{Dn}_{1}\right)$ was an outlier for mandible size: this was almost certainly because of an artefact in the original photography; the Filipov mandibles were still joined at the symphysis preventing them from being laid flat, distorting their size and shape through parallax (see also Fig. 3D). Many of the largest shrews were from high-altitude sites: Baikal, Cordon, Jura, Serov, Novosibirsk and Vaud samples. Previous studies have noted increased size at high altitudes (Homolka, 1980). The smallest shrews came from northern sites: Savukoski, Kuhmo, Hällefors and Öland. The correlation between skull centroid size and latitude of $R=-0.427$ suggests a weak latitudinal trend in which animals are smaller at high latitudes. The same pattern was previously reported in S. araneus by Ochocińska \& Taylor (2003), who discussed it as a departure from Bergmann's rule. 
Molar shape. Molar shape showed a strong eastwest cline (Fig. 3C). The eastern races of Serov, Baikal, and Novosibirsk were at the negative end of PC 1 and the western races of Cordon, Hermitage, Chysauster, and Jura races at the positive end. PC 1 had a strong correlation with longitude, $R=-0.718$. Some structuring was evident at the karyotypic level. Samples from the same race clustered loosely near one another (e.g., Novosibirsk, Ulm, Öland, Hermitage), and samples of $S$. coronatus and $S$. antinorii clustered near their conspecifics on the periphery of $S$. araneus. Despite the clustering, no karyotypic race grouped together exclusive of others. Variation in molar shape was nearly univariate, with 57\% concentrated on the first PC (Fig. 4), suggesting that the genetic variation underlying the cline is simple. Axes other than PC 1 explained very little variance and mostly differentiated single samples (such as the Hällefors race on PC 2 in Fig. 3C).

A
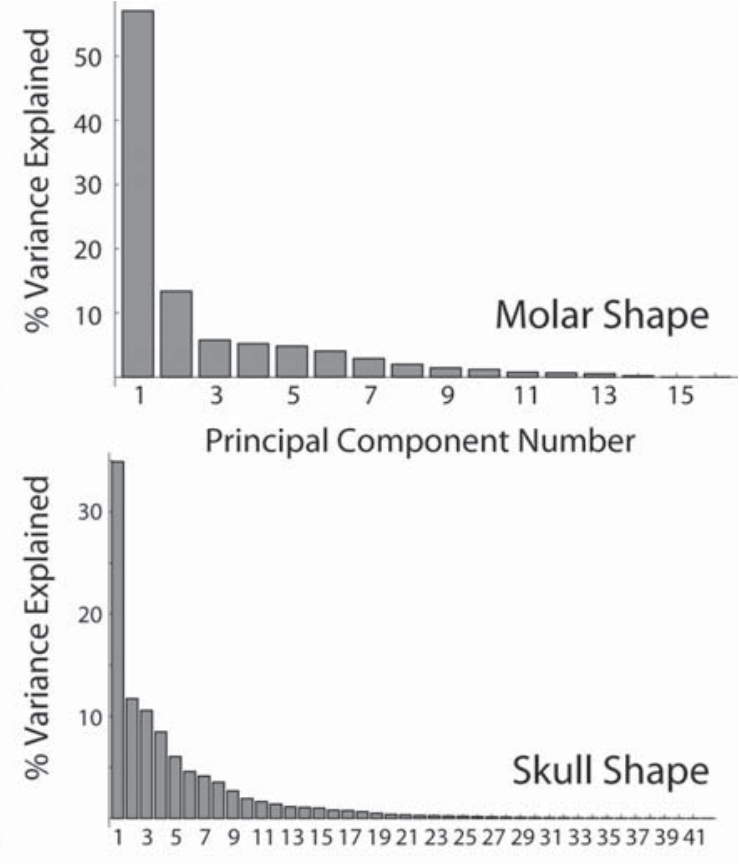

Principal Component Number

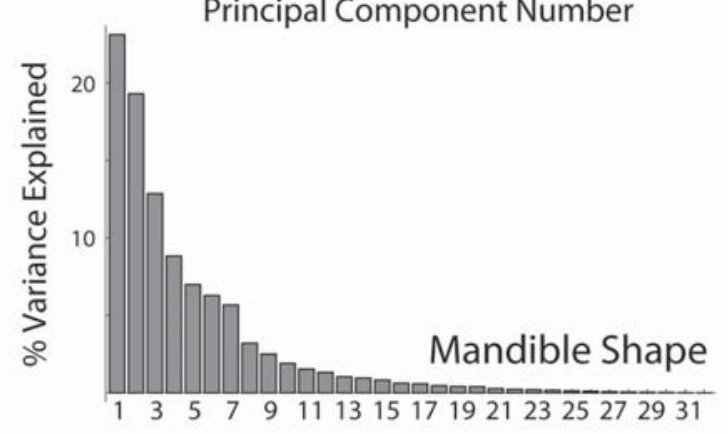

C

Principal Component Number

Figure 4. Percentage of total variance explained by individual principal components in molar shape (A), skull shape (B) and mandible shape $(\mathrm{C})$.
Skull shape. Skull shape had a weak east-west cline largely driven by the several western British races clustering at the negative end of PC 1 (Fig. 3B). The Siberian races were not at the opposite end suggesting that the trend is primarily in the western European karyotypic group. The correlation between PC 1 and longitude was substantially lower than in molars $(R=0.425)$. Separation of samples along PC 1 was on the basis of the proportional length of the rostrum and spacing of the antemolars: taxa at the negative end had short rostrums and small, closely spaced antemolars; the ones at the positive end had long rostrums and large antemolars.

A north-south cline in skull shape that has many of the morphological features seen in the east-west cline identified here was described in Scandinavia by Sulkava et al. (1985). In Scandinavia, northern shrews had long rostrums and large antemolars, while those to the south had shorter rostrums with closely spaced antemolars. It is likely that the Scandinavian cline is part of the larger east-west gradient identified here, but happens to run north-south through Scandinavia.

The east-west trend in skull shape is probably associated with a cline in which the frequency of missing fifth upper antemolars $\left(\mathrm{U}^{5}\right)$ increases westward. (Note that in shrews teeth between the first incisor and fourth premolar are called antemolars because their individual homologies with incisors, canines and premolars are contested). Polymorphic absence of that tooth has been reported before in German, Swedish, Finnish and British populations at the level of about $1-2 \%$, climbing as high as $52 \%$ on the island of Islay (Reinwald, 1961; Skarén, 1964; Schmidt, 1967; Corbet \& Southern, 1977; Hausser et al., 1990). Absence of $U^{5}$ was noted in five of the samples studied here: Aberdeen race from Dumbreck, Białowieża race, Chysauster race (both samples), Öland race from the south of the island and Ulm race from Stary Krakow (samples sizes were too small to accurately estimate the frequencies). In animals missing $\mathrm{U}^{5}$ the rostrum was notably shorter, making it likely that the variation in skull shape identified here is correlated with polymorphism in $\mathrm{U}^{5}$. Note that the Oxford race from Islay, which has the highest described frequency of missing $\mathrm{U}^{5}$, falls at the extreme negative end of PC 1 .

Mandible shape. No obvious geographic or taxonomic pattern below the species level was found in mandible shape (Fig. 3D). Mandible shape sorted the three species: Sorex coronatus was well separated in having a posteriorly projecting condyle and anteriorly projecting coronoid process, features noted by Hausser \& Jammot (1974) as being distinctive of the species. $S$. antinorii samples was also separated from $S$. araneus, but less so than $S$. coronatus. The differences in the mandible of $S$. antinorii were similar but less extreme than those in $S$. coronatus. Within $S$. araneus, mandible shape showed little correlation with karyotypic race, with group or with geography. Many of the British races (but not the Wirral) had negative values on PC 2 and so grouped towards the bottom centre of the plot. The Vaud samples clustered together at the negative end of PC 1, but were near the Savukoski, Öland and Baikal races. 

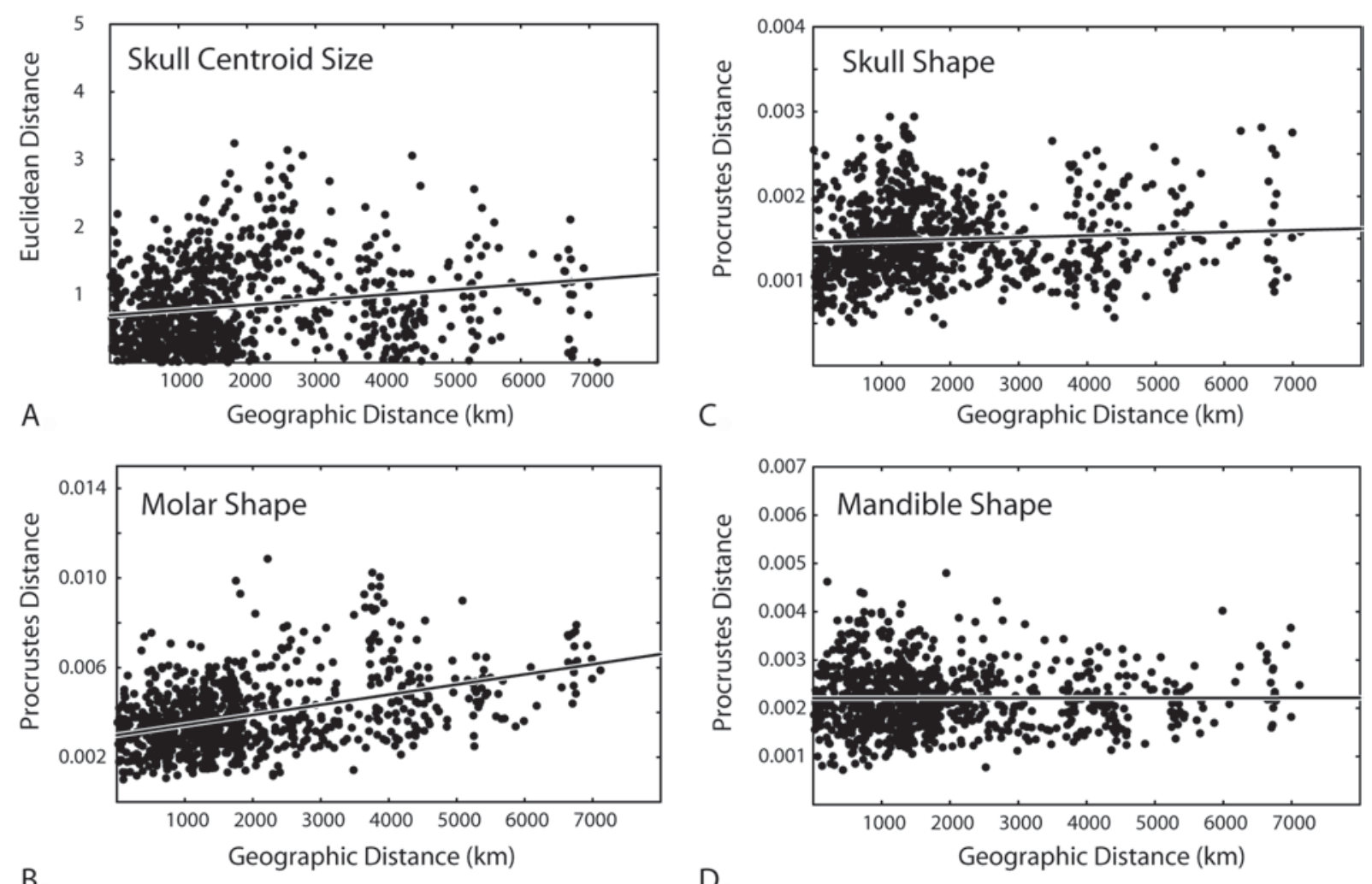

Figure 5. Isolation by distance in skull centroid size (A), skull shape (B), molar shape (C) and mandible shape (D).

The Drnholec sample from Filipov was an outlier at the positive end of PC 1, probably due to biased measurement as discussed above. Mandible shape variation was more complicated than the other structures, with only $23 \%$ of the variation explained by the first PC. PCs $2-7$ also explained appreciable portions of the variance.

\section{Isolation by distance}

Isolation by distance was assessed by comparing the morphological distance between sample pairs to their geographic distance from one another (Fig. 5). Association was tested using Mantel tests on the two distance matrices. Skull centroid size had a weak, but positive association with geographic distance $(R=0.18, p=0.00)$. Lower molar shape had a stronger association with geographic distance $(R=0.44, p=0.00)$, while skull shape had a marginal one $(R=0.07, p=0.02)$. Mandible shape did not have a significant association with geographic distance $(R=0.00, p=0.51)$. The geographic structuring in skull size is related to latitude and the structuring in molar shape to longitude, as described above.

\section{Morphological structuring and karyotypic races}

Structuring in morphology was measured with $F$ statistics. $F_{S T}$ was measured at four hierarchical levels: between populations of the same race, between races, between karyotypic groups, and between species. $F_{S T}$ is the amount of differentiation between groups compared to variation within them; the greater the value, the greater the structuring. The greatest structuring was found between populations of the same race and between karyotypic groups (Tab. 2). Mandible shape was most structured between populations and between species, but not between races or between karyotypic groups. Structuring between races was weak but significant for all four traits.

Table 2. Divergence in quantitative characters at four hierarchical levels.

\begin{tabular}{|l|c|c|c|c|}
\hline \multirow{2}{*}{} & \multicolumn{4}{|c|}{$F_{S T}$} \\
\cline { 2 - 5 } & $\begin{array}{c}\text { Skull } \\
\text { size }\end{array}$ & $\begin{array}{c}\text { Molar } \\
\text { shape }\end{array}$ & $\begin{array}{c}\text { Skull } \\
\text { shape }\end{array}$ & $\begin{array}{c}\text { Mandible } \\
\text { shape }\end{array}$ \\
\hline $\begin{array}{l}\text { Between } \\
\text { populations of } \\
\text { the same races }\end{array}$ & $\begin{array}{c}0.11 \\
( \pm 0.019)\end{array}$ & $\begin{array}{c}0.11 \\
( \pm 0.014)\end{array}$ & $\begin{array}{c}0.09 \\
( \pm 0.024)\end{array}$ & $\begin{array}{c}0.08 \\
( \pm 0.012)\end{array}$ \\
\hline Between races & $\begin{array}{c}0.04 \\
( \pm 0.004)\end{array}$ & $\begin{array}{c}0.04 \\
( \pm 0.001)\end{array}$ & $\begin{array}{c}0.01 \\
( \pm 0.002)\end{array}$ & $\begin{array}{c}0.01 \\
( \pm 0.001)\end{array}$ \\
\hline $\begin{array}{l}\text { Between } \\
\text { karyotypic } \\
\text { groups }\end{array}$ & $\begin{array}{c}0.13 \\
( \pm 0.019)\end{array}$ & $\begin{array}{c}0.15 \\
( \pm 0.009)\end{array}$ & $\begin{array}{c}0.05 \\
( \pm 0.005)\end{array}$ & $\begin{array}{c}0.04 \\
( \pm 0.003)\end{array}$ \\
\hline $\begin{array}{l}\text { Between } \\
\text { species }\end{array}$ & $\begin{array}{c}0.06 \\
( \pm 0.011)\end{array}$ & $\begin{array}{c}0.07 \\
( \pm 0.004)\end{array}$ & $\begin{array}{c}0.04 \\
( \pm 0.004)\end{array}$ & $\begin{array}{c}0.08 \\
( \pm 0.004)\end{array}$ \\
\hline
\end{tabular}



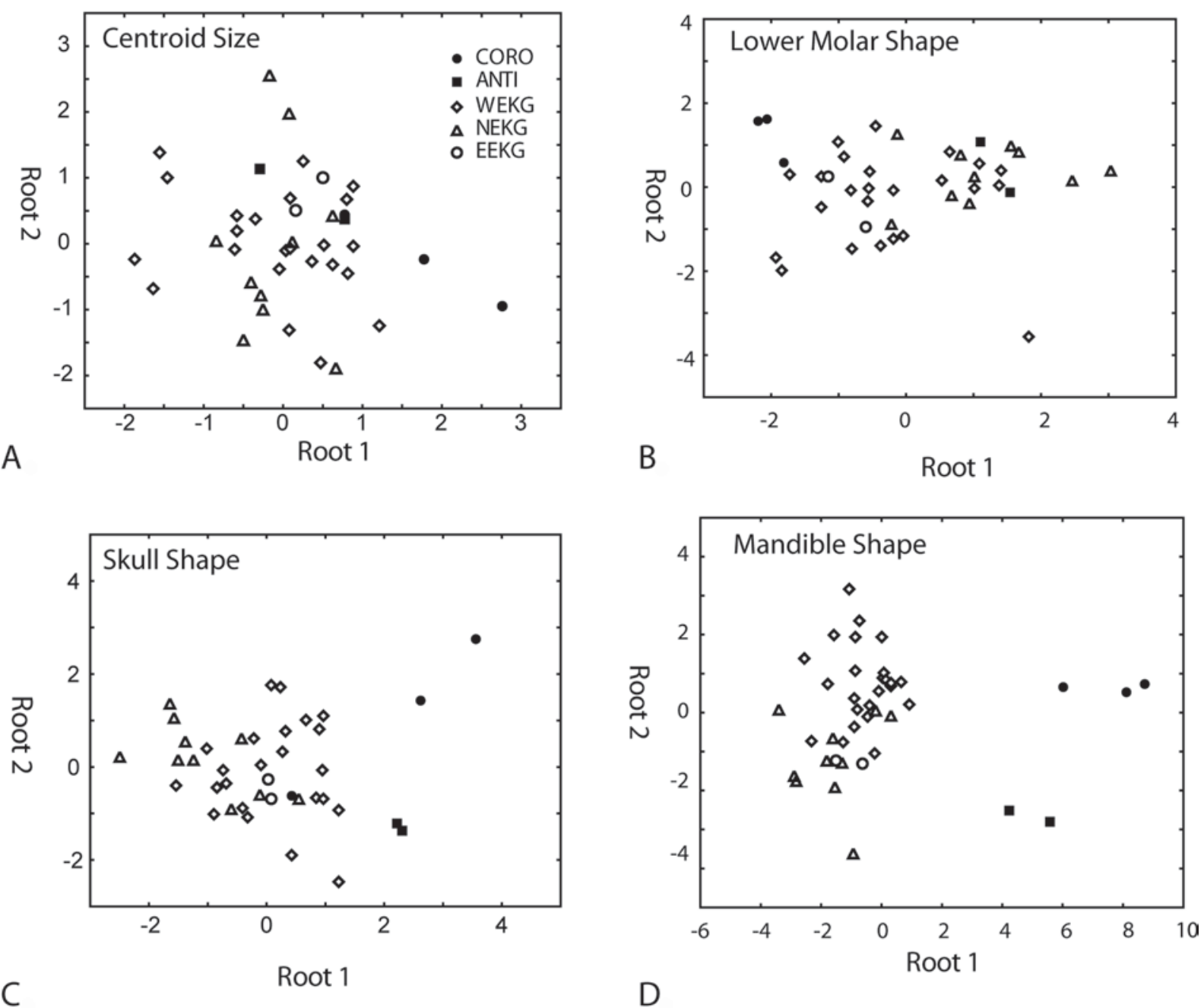

Figure 6. Discriminant function analysis results for karyotypic groups: skull centroid size (A); skull shape (B); molar shape (C); mandible shape (D). Abbreviations as in Tab. 1.

The randomization test showed that the association of morphology and karyotypic race was small but significant for shape but not size. Skull centroid size had a narrowly insignificant association with race $(p=0.057)$, but molar shape, skull shape, and mandible shape all had a strong association $(p=0.009,0.005$, and 0.0001 respectively). Thus, differences between races thus appear to be significant, even though the differentiation between them is small as measured by $F_{S T}$.

Discriminant function analysis and identification of fossils

Large $F_{S T}$ values between karyotypic groups for molar shape suggests that it is at this hierarchical level that fossil taxa can best be identified. The majority of fossil mammalian specimens are isolated teeth. Skulls and mandibles are seldom preserved intact and postcranial bones or non-molar teeth are often difficult to identify taxonomically at the species level. Discrimi- nant Functions Analysis (DFA) with cross-validation was used to test the accuracy with which specimens can be classified at the karyotypic group level using centroid size, molar shape, skull shape and mandible shape (Fig. 6, Tab. 3). Molar and mandible shape were best

Table 3. Percentage of samples referred correctly to karyotypic group by canonical Discriminant Function Analysis. Abbreviations are the same as in Tab. 1.

\begin{tabular}{|l|c|c|c|c|}
\hline \multirow{2}{*}{} & \multicolumn{4}{|c|}{ Percent correct } \\
\cline { 2 - 5 } & Centroid size & Lower molars & Skulls & Mandibles \\
\hline CORO & $33.3 \%$ & $66.7 \%$ & $66.7 \%$ & $100.0 \%$ \\
\hline ANTI & $0.0 \%$ & $50.0 \%$ & $100.0 \%$ & $100.0 \%$ \\
\hline WEKG & $100.0 \%$ & $87.5 \%$ & $95.8 \%$ & $95.8 \%$ \\
\hline NEKG & $0.0 \%$ & $50.0 \%$ & $60.0 \%$ & $70.0 \%$ \\
\hline EEKG & $0.0 \%$ & $0.0 \%$ & $0.0 \%$ & $0.0 \%$ \\
\hline Total & $61.0 \%$ & $70.7 \%$ & $80.5 \%$ & $85.4 \%$ \\
\hline
\end{tabular}


for classifying specimens $(80.5 \%$ and $85.4 \%$ accurate overall respectively) and centroid size was worst (61.0\% accurate overall). Mandibles were able to discriminate the three species $100 \%$ of the time. In cases where the eastern European group was misclassified, it was classified as the western European group.

\section{Discussion}

The remarkable karyotypic diversity of Sorex araneus has often been contrasted to its comparative morphological homogeneity. The results presented here demonstrate that the morphological structuring exists in the species, though the actual differences are small and more easily measured than observed.

Morphological structuring is complicated and the pattern differs from trait to trait. Structuring as measured by $F_{S T}$ is greatest at the population and karyotypic group levels for three out of four of the traits (mandible shape being the exception) and weakest at the level of the karyotypic race. This means that differences between populations within a race are often greater than differences between populations from different races or even different species. Large-scale east to west clines exist in skull and molar shape, but not in mandible shape. Mandible shape has no obvious clines within $S$. araneus, but differs more than skulls and molars between species. Overall, the greatest structuring at all levels occurs in molar shape, possibly because tooth phenotypes are not susceptible to structural remodelling after mineralization, unlike skulls and mandibles (Polly, 2001, 2003; Caumul \& Polly, 2005). The genetic variance of molars is thus probably higher proportional to the environmental variance than in skull and mandible shape; nongenetic ecophenotypic responses to local environmental factors probably obscure structuring in the latter traits.

High local variation in morphological size and shape is consistent with molecular studies that found high local genetic diversity within races (Lugon-Moulin et al., 2000; Bannikova et al., 2003; Ratkiewicz et al., 2003) and with morphometric studies that found greater morphometric differences within races than between them (Searle \& Thorpe, 1987; Wójcik et al., 2000; Banaszek et al., 2003). The between population $F_{S T}$ values measured here $(0.08-0.11)$ are comparable to those measured between populations using microsatellite and allozyme data (0.03-0.14; Fivaz et al., 2003; Ratkiewicz et al., 2003; Andersson et al., 2004). The implications are important for morphometric studies related to karyotype: when only two samples are being compared, the differences are more likely to be local than to be karyotypic. For example, the findings by Polly (2001) of significant differences in molar shape between the Aberdeen and Oxford karyotypic races may really reflect population-level rather than racelevel differentiation. To adequately assess difference between races, many samples from each may be required like in the studies by Polyakov et al. (2002) and Okulova et al. (2004). One supposes that populationlevel variation is transient, generated by stochastic (or selectional) changes in small local populations and reabsorbed by gene flow in the metapopulation, because the $F_{S T}$ values are lower at the level of karyotypic race, the next rung in the hierarchy. If the population-level variation were permanent, then we would expect differences between races, karyotypic groups and species to be greater. The generation of transient local variation probably ensures rapid phenotypic change in certain conditions, such as founder effects. The population on the island of Islay in western Scotland may be an example, where the frequency of polymorphic absence of the upper fifth antemolar reaches 52\% (Corbet \& Southern, 1977).

Morphological differentiation between karyotypic races is small, but significant. The morphological $F_{S T}$ values ranged from 0.01 to 0.04 , but all were significantly greater than 0 . Furthermore, the differences between populations within races were significantly smaller than differences between random populations from different races. Even though racial differences are easily obscured by population-level variation, it appears that karyotype boundaries do influence morphological variation. The effect of karyotype was much greater at the group level than at the level of individual races. $F_{S T}$ between karyotypic groups ranged from 0.04 in mandible shape to a stunning 0.15 in molar shape. This pattern suggests significant genetic divergence among the karyotypic groups, probably corresponding to deeper phylogeographic divergences among the groups than among their constituent races. The northern and western karyotypic groups were as differentiated from one another as they were from the species Sorex coronatus and $S$. antinorii in all traits except mandibular shape. Interestingly, the eastern karyotypic group was not well differentiated from the western group, suggesting that the split between the two is more recent than between the western and northern groups. Ratkiewicz et al. (2002) found that there was little cytochrome $b$ differentiation between these two groups and concluded that their chromosomal differences were recent.

The pattern of morphological structuring identified here has implications for the determination of fossil material to subspecific groupings within $S$. araneus. The low level of differentiation between races of the same karyotypic group compared to the populationlevel variability probably means that fossil specimens, whose sample size is typically small, cannot be determined to the level of race. They can, however, be reasonably accurately assigned to karyotypic groups. The dating of the Oxford-Hermitage race split by Polly (2001) may need to be re-examined in this light, because that study included only members of the western karyotypic group. Furthermore, that study linked fossil samples from the Late Glacial and Riss-Würm interglacial periods to the Oxford and Hermitage clades respectively but only included one sample from the Hermitage race. If the differentiation in that sample was transient and not representative of the race as a whole, then the association with the interglacial fossil sample may have been spurious. Further studies are required to confirm or refute those results. 


\section{Conclusion}

Do chromosomal mutations lead to speciation? The results presented here suggest that morphological divergence in the common shrew is, on a broad scale, correlated with karyotypic divergence. Morphological structuring in relation to karyotype is present in Sorex araneus at several hierarchical levels. Morphological differentiation is strongest at the level of karyotypic group and there are small but significant differences between individual races. This hierarchical pattern suggests that the karyotypic groups originated before their constituent races, though the timescale of origination cannot be resolved with the data presented here. Mandible shape appears to evolve more quickly than molar or skull shape because the differences between species are larger in the former than the latter. Molar shape, which probably has the highest genetic component of any of the traits examined in this study, has structuring at all levels, more so than size, skull shape or mandible shape. The presence of structuring suggests that genetic differences are significant among karyotypic races, and the hierarchical pattern suggests that the genetic differences have built up in successive stages. The view that current diversity within $S$. araneus is being homogenized because of gene flow across secondary hybrid zones (Bengtsson \& Frykman, 1990) appears to be incompatible with the patterns of morphological structuring found here.

ACKNOWLEDGMENTS. Karl Fredga, Olavi Grönwall, Jacques Hausser, Jeremy Searle, Haidee Price-Thomas, Laurent Vallotton, Jan Wójcik and Jan Zima all generously provided shrew specimens and associated data. Andrea Cardini, Pavel Borodin, Karl Fredga, Jacques Hausser, Ross Jones, Alina Mishta, Andrei Polyakov, Eugene Poroshin, Jeremy Searle, Tom White, Jan Wójcik and Jan Zima provided discussions or information that improved the paper. Steve Le Comber discussed statistical strategies. Any errors or misinterpretations are solely those of the author. Andrei Polyakov graciously translated the abstract into Russian. Thanks to Jeremy Searle, Nina Bulatova and Alexander Averianov for their work editing this volume. The work was supported by the UK Natural Environment Research Council (GR3/12996) and the Leverhulme Trust (F/07476/Q).

\section{References}

Andersson A.-C. 2004. Postglacial population history of the common shrew (Sorex araneus) in Fennoscandia: molecular studies of recolonization, sex-biased gene flow, and the formation of chromosome races // Comprehensive Summaries of Uppsala Dissertations of the Faculty of Science and Technology. Vol.986: Acta Universitatis Upsaliensis, Uppsala.

Andersson A.-C., Narain Y., Tegelström H. \& Fredga K. 2004. No apparent reduction of gene flow in a hybrid zone between the West and North European karyotypic groups of the common shrew, Sorex araneus // Molecular Ecology. Vol.13. P.1205-1215.

Balloux F., Brünner H., Lugon-Moulin N., Hausser J. \&
Goudet J. 2003. Microsatellites can be misleading: an empirical and simulation study // Evolution. Vol.54. P.1414-1422.

Banaszek A., Smakulska J., Fedyk S., Jadwiszczak K.A. \& Chętnicki W. 2003. Morphometric differentiation of shrews (Sorex araneus L., 1758) from the hybrid zone between the Guzowy Młyn and Łęgucki Młyn chromosome races in Poland // Mammalia. Vol.67. P.217-224.

Bannikova A.A., Bulatova N.S., Krysanov E.Y. \& Kramerov D.A. 2003. DNA polymorphism within Sorex araneus and two congeneric species as inferred from inter-SINEPCR // Mammalia. Vol.67. P.263-274.

Bengtsson O. \& Frykman I. 1990. Karyotype evolution: evidence from the common shrew (Sorex araneus L.) // Journal of Evolutionary Biology. Vol.3. P.85-101.

Bookstein F.L. 1991. Morphometric Tools for Landmark Data. Cambridge: Cambridge University Press.

Brünner H., Lugon-Moulin N., Balloux F., Fumagalli L. \& Hausser J. 2002. A taxonomical re-evaluation of the Valais chromosome race of the common shrew Sorex araneus (Insectivora: Soricidae) // Acta Theriologica. Vol.47. P.245-275.

Caumul R. \& Polly P.D. 2005. Comparative phylogenetic and environmental components of morphological variation: skull, mandible and molar shape in marmots (Marmota, Rodentia) // Evolution. Vol.59. P.2460-2472.

Churchfield S. 1990. The Natural History of Shrews. Ithaca, New York: Comstock Publishing Associates.

Corbet G.B., Southern H.N. 1977. The Handbook of British Mammals. Oxford: Blackwell Scientific Publications.

Dryden I.L \& Mardia K.V. 1998. Statistical Analysis of Shape. New York: John Wiley \& Sons.

Fivaz F., Basset P., Lugon-Moulin N. \& Hausser J. 2003. Postglacial recolonization of the Valais (Switzerland) by the shrew Sorex antinorii: Is dispersal sex-biased? A preliminary study // Mammalia. Vol.68. P.253-362.

Fredga K. 1996. The chromosome races of Sorex araneus in Scandinavia // Hereditas. Vol.125. P.123-135.

Frykman I. \& Bengtsson B.O. 1984. Genetic differentiation in Sorex. III. Electrophoretic analysis of a hybrid zone between two karyotypic races in Sorex araneus // Hereditas. Vol.100. P.259-270.

Frykman I., Simonsen V. \& Bengtsson B.O. 1983. Genetic differentiation in Sorex. I. Electrophoretic analysis of the karyotypic races of Sorex araneus in Sweden // Hereditas. Vol.99. P.279-292.

Halkka L., Söderlund V., Skarén U. \& Heikkilä J. 1987. Chromosomal polymorphism and racial evolution of Sorex araneus L. in Finland // Hereditas. Vol.106. P.257-275.

Hausser J. \& Jammot D. 1974. Etude biométrique des mâchoires chez les Sorex du groupe araneus en Europe continentale (Mammalia, Insectivora) // Mammalia. Vol.38. P. 324-343.

Hausser J. 1994. The Sorex of the araneus-arcticus group (Mammalia: Soricidae): do they actually speciate? // Merrit J.F., Kirkland G.L., Jr. \& Rose R.K. (eds.). Advances in the Biology of Shrews. Carnegie Museum of Natural History Special Publication. Vol.8. P.295-306.

Hausser J., Hutterer R. \& Vogel P. 1990. Sorex araneus Linnaeus, 1758 - Waldspitzmaus. // Niethammer J. \& Krapp F. (eds.). Handbuch der Säugetiere Europas. Wies- 
baden: AULA-Verlag. P.237-278.

Homolka M. 1980. Biometrischer Vergleich zweier Populationen Sorex araneus // Acta Scientiarum Naturalium Academiae Scientiarum Bohemicae Brno. Vol.14. P.1-34.

Ivanitskaya E. 1994. Comparative cytogenetics and systematics of Sorex: a cladistic approach // Merrit J.F., Kirkland G.L., Jr. \& Rose R.K. (eds.), Advances in the Biology of Shrews. Carnegie Museum of Natural History Special Publication. Vol.8. P.313-323.

Lande R. 1992. Neutral theory of quantitative genetic variance in an island model with local extinction and colonization // Evolution. Vol.46. P.381-389.

Lougon-Moulin N., Balloux F., \& Hausser J. 2000. Genetic differentiation of common shrew Sorex araneus populations among different alpine valleys revealed by microsatellites // Acta Theriologica. Vol.45. Suppl.1. P.103-117.

Manly B.F.J. 1991. Randomization, Bootstrap and Monte Carlo Methods in Biology. New York: Chapman and Hall.

Ochocińska D. \& Taylor J.R.E. 2003. Bergmann's rule in shrews: geographical variation of body size in Palearctic Sorex species // Biological Journal of the Linnean Society. Vol.78. P.365-381.

Okulova N.M., Balakirev A.E. \& Orlov V.N. 2004. [Craniometrical characteristics of some Sorex araneus (Insectivora) chromosomal races]// Zoologicheskii Zhurnal. Vol.83. P.1476-1487 [in Russian, with English summary].

Polly P.D. 2001. On morphological clocks and paleophylogeography: Towards a timescale for Sorex hybrid zones // Genetica. Vol.112/113. P.339-357.

Polly P.D. 2003. Paleophylogeography of Sorex araneus: molar shape as a morphological marker for fossil shrews // Mammalia. Vol.68. P.233-243.

Polyakov A.V., Onischenko S.S., Ilyashenko V.B., Searle J.B. \& Borodin P.M. 2002. Morphometric difference between the Novosibirsk and Tomsk chromosome races of Sorex araneus in a zone of parapatry // Acta Theriologica. Vol.47. P.381-387.

Polyakov A.V., Panov V.V., Ladygina T.Yu., Bochkarev M.N., Rodionova M.I. \& Borodin P.M. 2001. Chromosomal evolution of the common shrew Sorex araneus L. from the southern Urals and Siberia in the postglacial period // Russian Journal of Genetics. Vol.37. P.351-357.

Ratkiewicz M., Banaszek A., Jadwiszczak K., Chętnicki W. \& Fedyk S. 2003. Genetic diversity, stability of population structure and barriers to gene flow in a hybrid zone between two Sorex araneus chromosome races // Mammalia. Vol.68. P.275-283.

Ratkiewicz M., Fedyk S., Banaszek A., Chętnicki W., Szałaj K., Gielly L. \& Taberlet P. 2002. The evolutionary history of the two karyotypic groups of the common shrew, Sorex araneus, in Poland // Heredity. Vol.88. P.235-242.

Reinwaldt E. 1961. Über Zahnanomalien und die Zahnformel der Gattung Sorex Linné // Arkiv för Zoologi. Vol.13. P.533-539.

RohlfF.J. 1990. Rotational fit Procrustes methods // RohlfF.J. \& Bookstein F.L. (eds.). Proceedings of the Michigan Morphometrics Workshop, University of Michigan Museum of Zoology Special Publication. Vol.2. P.227-236.

Rohlf F.J. \& Slice D. 1990. Extensions of the Procrustes method for the optimal superimposition of landmarks // Systematic Zoology. Vol.39. P.40-49.

Schmidt E. 1967. Unregelmässigkeiten der Zahl der Alveolen and den oberen einspitzigen Zähnen bei der Waldspitzmaus. // Acta Theriologica. Vol.12. P.665-689.

Searle J.B. 1984. Three new karyotypic races of the common shrew Sorex araneus (Mammalia: Insectivora) and a phylogeny // Systematic Zoology. Vol.33. P.184-194.

Searle J.B. 1985. Isozyme variation in the common shrew (Sorex araneus) in Britain in relation to karyotype // Heredity. Vol.55. P.175-180.

Searle J.B., Hübner R., Wallace B.M.N. \& Garagna S. 1990. Robertsonian variation in wild mice and shrews // Chromosomes Today. Vol.10. P.253-263.

Searle J.B. \& Thorpe R.S. 1987. Morphometric variation of the common shrew (Sorex araneus) in Britain in relation to karyotype and geography // Journal of Zoology. Vol.212. P.373-377.

Searle J.B. \& Wójcik J.M. 1998. Chromosomal evolution: the case of Sorex araneus // Wójcik J.M. \& Wolsan M. (eds.). Evolution of Shrews. Białowieża: Mammal Research Institute, Polish Academy of Sciences. P.173-218.

Skarén U. 1964. Variation in two shrews, Sorex unguiculatus Dobson and S. a. araneus L. // Annales Zoologici Fennici. Vol.1. P.94-124.

Sulkava S., Vahtola M. \& Fredga K. 1985. Structure of the upper tooth-row of Sorex araneus in Scandinavia // Acta Zoologica Fennica. Vol.173. P.237-239.

Spitze K. 1993. Population structure in Daphnia obtusa: quantitative genetic and allozymic variation // Genetics. Vol.135. P.367-374.

Weir B.S. \& Cockerham C.C. 1984. Estimating $F$-statistics for the analysis of population structure // Evolution. Vol.38. P.1358-1370.

White M.J.D. 1978. Modes of Speciation. San Francisco: W.H. Freeman and Company.

Wójcik J.M. 1993. Chromosome races of the common shrew Sorex araneus in Poland: a model of karyotype evolution // Acta Theriologica. Vol.38. P.315-338.

Wójcik J.M., Bogdanowicz W., Pucek Z., Wójcik A.M. \& Zalewska H. 2000. Morphometric variation of the common shrew Sorex araneus in Poland in relation to karyotype // Acta Theriologica. Vol.45. Suppl.1. P.161-172.

Wójcik J.M., Borodin P.M., Fedyk S., Fredga K., Hausser J., Mishta A., Orlov V.N., Searle J.B., Volobouev V.T. \& Zima J. 2003. The list of the chromosome races of the common shrew Sorex araneus (updated 2002) // Mammalia. Vol.67. P.169-178.

Wójcik J.M. \& Wójcik A.M. 1994. Protein variation in the common shrew (Sorex araneus L.) in Poland in relation to karyotype // Folia Zoologica. Vol.43. Suppl.1. P.53-61.

Wójcik J.M., Wójcik A.M. \& Sikorski M.D. 2003. Morphometric variation in the common shrew, Sorex araneus, in different habitats // Mammalia. Vol.67. P.225-231.

Wright S. 1951. The genetic structure of populations // Annals of Eugenics. Vol.15. P.323-354.

Zima J., Slivková L. \& Tomáškova L. 2003. New data on karyotypic variation in the common shrew, Sorex araneus, from the Czech Republic: an extension of the range of the Laska race // Mammalia. Vol.67. P.209-215. 